\title{
Subfossil cladoceran assemblages in the sediment core from the Arctic Lake Arkto- Pimberto of the Pechora Delta (Nenets Autonomous Okrug, Russia)
}

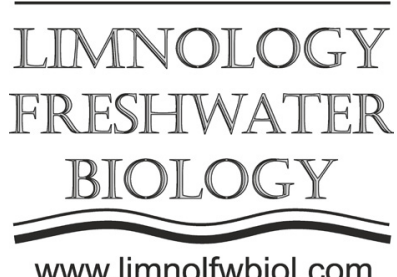

www.limnolfwbiol.com

\author{
Nigmatullin N.*, Frolova L. \\ Kazan Federal University, Kremlevskaya Str., 4/5, Kazan, 420008, Russia
}

\begin{abstract}
This paleoecological investigation is based on the analysis of bottom sediment columns sampled during a summer research expedition in 2018 from the Arctic Lake Arkto-Pimberto, which is located within the Pechora River delta in the Nenets State Nature Reserve. Lake Arkto-Pimberto is of great interest for research due to several reasons: it is round in shape and small in diameter; its depth is less than $2 \mathrm{~m}(9 \mathrm{~m})$; the lake has not been subjected to any anthropogenic influence. Our investigation shows that the cladoceran communities of the studied lake are diverse and abundant. In total, 16 Cladocera taxa were found in the samples. Most of the identified taxa belong to the Chydoridae family. The Bosminidae family includes only two species. Bosmina longispina was the absolute dominant among the subfossil remains of Cladocera. The subdominants were represented by Chydorus cf. sphaericus, Alona affinis, and Rhynchotalona falcata. The Shannon diversity index varied from 0.86 to 1.85 . According to the Pantle-Buck saprobity index modified by Sladecek, the lake is mesosaprobic.
\end{abstract}

Keywords: paleoecology, Arctic Lake, Pechora River delta, cladoceran communities

\section{Introduction}

Cladocera, as one of the major zooplankton groups, play a central role in the flow of energy in pelagic food webs. The ecological position of Cladocera in the middle of the food web makes them very suitable to track short- and long-term environmental changes and top-down or bottom-up processes (Bledzki, 2016). Their chitinous exoskeletal parts (shell, head shield, postabdomen, postabdominal claws, antennal segments, and mandibles) are usually well preserved in sediments and most are identifiable to the species level (Frolova, 2014). Paleoclimatic investigations specify how the climate and environmental situation of particular regions and water objects changed in the past and enable us to map their evolution for the future, as well as to identify the development trends of the Earth's climate as a whole (Frolova, 2016). This study provides a paleoecological reconstruction of the development history of Lake Arkto-Pimberto using Cladocera analysis.

\section{Materials and Methods}

Four cores were sampled from the Arctic Lake Arcto-Pimberto $\left(68^{\circ} 26^{\prime} 10.7^{\prime \prime} \mathrm{N} 053^{\circ} 32^{\prime} 34.4^{\prime \prime} \mathrm{E}\right)$ in the Pechora delta. For our investigation, we used sediment core 18-Pe-01C. All sediment samples involved in the subsequent Cladocera analysis were studied using the standard techniques described in Szeroczynska and Sarmaja-Korjonen (2007). Fresh surface sediment samples, taken in the amount of 0.15-0.18 g, were heated in $10 \% \mathrm{KOH}$ at $80^{\circ}$ for about $30 \mathrm{~min}$. The sediments were then rinsed through $50 \mu \mathrm{m}$ sieves. The material retained on sieves was transferred to small vials containing distilled water and a few drops of ethanol. The samples were examined under an AxioLab A1 light microscope at $100-400 \times$ magnification. The chitinous remains of Cladocera were identified according to Kotov (2010) and Szeroczynska (2007).

\section{Results and Discussion}

A total of 16 Cladocera taxa, belonging mostly to the family Chydoridae, were identified in this lake. In sediment core 18-Pe-01C, 3939 specimens of Cladocera were found. The average number of Cladocera specimens per sample was $207 \pm 5$, with a minimum of 127 specimens and a maximum of 251 specimens. The number of taxa per sample varied from 7 to 12 . Among other species, Bosmina (Eubosmina) longispina (72.66\% of the total number of identified cladocerans) belonging to the family Bosminidae is dominant. This species inhabits central, northern, and eastern regions of Europe and has been reported from lakes and reservoirs. The following taxa are subdominant in 
the lake: Chydorus cf. sphaericus (12.77\%) - the taxon has perfectly adapted to life in the littoral area of the lake; Alona affinis (6.07\%) - the species is an indicator of the cold periods and is classified as "sub-Arctic" because of its relatively high frequency in the Arctic; Rhynchotalona falcata (4.11\%) - the benthic species, which is widely distributed in Europe. According to the zoogeographical zoning, Holarctic and Palearctic species are the largest contributors to the species diversity of Lake Arkto-Pimberto. In the Cladocera group, the littoral taxa $(67 \%)$ prevail, while pelagic (17\%) and eurytopic (17\%) species are less abundant. The calculated Shannon index reflecting the species diversity and indirectly indicating the water quality varied within the range of $0.86-1.85 \mathrm{bit} / \mathrm{ind}$. The average value of the index was $1.44 \pm 0.06$ bit/ind., which is typical for the $\beta$-mesotrophic zone. The saprobity index calculated for the Pantle-Buck index modified by Sladecek equaled $1.42 \pm 0.01$ on average, which is typical for the oligosaprobic conditions of water ecosystems.

\section{Conclusions}

We investigated the subfossil cladoceran community of Lake Arkto-Pimberto in the Pechora delta. A total of 16 cladoceran taxa were identified in sediment core 18-Pe-01C. Bosmina (Eubosmina) longispina, an oligotrophic species of cold waters, was the absolute dominant species in the core. The subdominant species were Chydorus cf. sphaericus, Alona affinis, and Rhynchotalona falcata. The species diversity of the studied lake is mostly determined by northern species. Cladocerans of the studied lake were dominated by the littoral taxa, and the littoral zone is the largest area of the studied lake. The historical formation of the lake was even. Based on the Shannon index, the studied lake is $\beta$-mesotrophic. According to the average value of the Pantle-Buck saprobity index modified by Sladecek, the lake is oligosaprobic.

\section{Acknowledgements}

The laboratory research was funded by the Russian Science Foundation (project no. 20-17-00135) and performed according to the Russian Government Program of Competitive Growth of Kazan Federal University. The field work was carried out with the support of the Russian Foundation for Basic Research (project no. 18-05-00406).

\section{References}

Bledzki L.A., Rybak J.I. 2016. Freshwater crustacean zooplankton of Europe. In: Springer International Publishing, Switzerland.

Frolova L., Ibragimova A., Fedorova I. 2016. Stratigraphy of Cladocera in a core from a Yamal peninsula lake (Arctic Russia), 16th International Multidisciplinary Scientific GeoConference, SGEM 2016, Bulgaria, vol.2, pp. 579-585,

Frolova L., Nazarova L., Pestryakova L., Herzschuh U. 2014. Subfossil Cladocera from surface sediment in thermokarst lakes in northeastern Siberia, Russia, in relation to limnological and climatic variables, Journal of Paleolimnology 52: 107-119.

Kotov A.A., Sinev A.Ju., Glagolev S.M., Smirnov N.N. 2010. Cladocera in Identification Key of zooplankton and zoobenthos of European Russia freshwater. In: Alekseeva V. R., Calolihina S. Ja. (Ed.). Moscow: Partnership of scientific publications KMK.

Szeroczynska K., Sarmaja-Korjonen K. 2007. Atlas of Subfossil Cladocera from Central and Northern Europe. In: Friends of the Lower Vistula Society. 